\title{
KAJIAN POTENSI HIDROLOGI EMBUNG IRIGASI WAE ROBANG DI KABUPATEN ROTE NDAO
}

\author{
Study The Potential Of Hidrology Wae Robang Irrigation Retention Basin In Rote Ndao Disrtrict
}

\author{
Siti Nurasiyah \\ Departemen Pendidikan Teknik Sipil, Universitas Pendidikan Indonesia \\ email: iisnurasiyah82@yahoo.com
}

\begin{abstract}
Rote Ndao District is one of the districts in the province of NTT, which has a fairly extensive irrigation areas and potential but less discharge to irrigate the irrigation area. Rote Ndao District has topography is hilly and much of the basin area can hold water, so one way to solve this problem is to build retention basin to hold excess water during the rainy season. Wae Robang retention basin is one of the retention basin will be built in Rote Ndao District. One aspect that must be examined in the planning of retention basin is hydrological analysis. The purpose of the analysis of hydrology at the location of Robang Wae retention basin is to assess the potential of existing hydrological includes inflows fill retention basin, retention basin reservoirs, and flood discharge plan. From the results of the hydrological analysis showed that the volume of water that can fill an Wae Robang retention basin during the rainy season amounted to $1,774,029 \mathrm{~m}^{3}$, retention basin reservoir design capacity Wae Robang retention basin amounted to $1,348,859 \mathrm{~m}^{3}$, and the flood discharge plan with a return period of 50 years for the spillway Wae Robang retention basin amounted to $21.71 \mathrm{~m}^{3} / \mathrm{sec}$.
\end{abstract}

Keywords: Wae Robang, retention basin, hydrologi

\begin{abstract}
Abstrak
Kabupaten Rote Ndao merupakan salah satu kabupaten di provinsi NTT yang memiliki areal irigasi yang cukup luas dan cukup potensial tetapi kekurangan debit air untuk mengairi areal irigasi tersebut. Kabupaten Rote Ndao ini memiliki kondisi topografi yang berbukit-bukit dan banyak daerah cekungan yang dapat menampung air, maka salah satu cara untuk menanggulangi masalah ini adalah dengan membangun embung yang berguna untuk menampung air yang berlebihan pada waktu musim hujan. Embung Wae Robang merupakan salah satu embung yang akan dibangun di Kabupaten Rote Ndao. Salah satu aspek yang harus ditelaah dalam perencanaan embung adalah analisis hidrologi. Tujuan dari analisis hidrologi di lokasi embung Wae Robang ini adalah untuk mengkaji potensi hidrologi yang ada meliputi aliran masuk yang mengisi embung, tampungan embung, dan debit banjir rencana. Dari hasil analisis hidrologi didapatkan bahwa volume air yang dapat mengisi kolam Embung Wae Robang selama musim hujan adalah sebesar $1.774 .029 \mathrm{~m}^{3}$, kapasitas tampung desain embung Wae Robang adalah sebesar $1.348 .859 \mathrm{~m}^{3}$, dan debit banjir rencana dengan kala ulang 50 tahun untuk pelimpah embung Wae Robang adalah sebesar $21,71 \mathrm{~m}^{3} /$ det.
\end{abstract}

Kata kunci : Wae Robang, embung, hidrologi

\section{PENDAHULUAN}

Kabupaten Rote Ndao merupakan salah satu kabupaten di provinsi Nusa Tenggara Timur (NTT) yang memiliki areal irigasi yang cukup luas dan cukup potensial tetapi kekurangan debit air untuk mengairi areal irigasi tersebut. Kabupaten Rote Ndao ini memiliki kondisi topografi yang berbukit-bukit dan banyak daerah cekungan yang dapat menampung air maka salah satu cara untuk menanggulangi masalah ini adalah dengan membangun Embung.
Membangunan embung merupakan salah satu upaya untuk menampung air yang berlebihan pada waktu musim hujan sehingga tidak terbuang percuma dan dapat dipakai untuk irigasi dan sumber air baku bagi masyarakat yang ada di daerah ini.

Salah satu aspek yang harus ditelaah dalam perencanaan embung adalah analisis hidrologi. Tujuan dari analisis hidrologi di lokasi embung ini adalah untuk mengkaji potensi hidrologi yang ada meliputi aliran masuk (inflow) yang mengisi embung, tampungan embung, dan debit banjir rencana. 


\section{METODE PENELITIAN}

Tahapan dalam analisis hidrologi untuk perencanaan embung meliputi :

- $\quad$ Aliran masuk yang mengisi embung

- Tampungan Embung

- Banjir Rencana

Pengumpulan data merupakan proses awal dalam pelaksanaan analisis hidrologi. Data yang dikumpulkan berupa data sekunder maupun maupun data primer berupa hasil survei di lapangan yang akan memberikan informasi awal mengenai kondisi di lapangan.

Pengumpulan data sekunder didapat dari instansi terkait, yaitu :

- Badan Koordinasi Survey dan Pemetaan Nasional (Bakosurtanal)

- Badan Meteorologi dan Geofisika Lasiana Provinsi Nusa Tenggara Timur

- Pusat Penelitian dan Pengembangan Sumber Daya Air

- Badan Perencanaan Pembangunan (Bappeda) Provinsi Nusa Tenggara Timur.

Data-data yang berhasil dikumpulkan untuk kepentingan analisis hidrologi adalah sebagai berikut

- Data Hujan : Data hujan yang digunakan untuk analisis adalah yang berpengaruh di wilayah studi, yaitu Stasiun Lembor (1990-1997).

- Data Iklim : Data iklim yang digunakan adalah dari stasiun klimatologi terdekat yaitu Stasiun Klimatologi Werang.

- Data Debit : Data debit yang berhasil dikumpulkan adalah data debit harian Pos Duga Air Lembor (1997). Data debit jam-jaman yang digunakan untuk kalibrasi adalah dari pos duga air terdekat yaitu dari Pos Duga Air Magepanda.

- Data Kependudukan : Data jumlah penduduk didapat dari Bappeda Provinsi Nusa Tenggara Timur.

\section{HASIL DAN PEMBAHASAN}

\section{Perkiraan Debit Aliran Masuk Embung}

Untuk memperkirakan besarnya aliran masuk ke dalam kolam embung Pusat Penelitian dan
Pengembangan Sumber Daya Air telah menyederhanakan cara analisisnya berdasarkan model NRECA. Pengembangan dengan model ini telah dilakukan sejak tahun 1992 dengan mengambil contoh lokasi di Nusa Tenggara Timur (NTT).

Debit aliran masuk ke dalam embung berasal dari hujan yang turun di dalam daerah cekungan. Sebagian dari hujan tersebut menguap, sebagian lagi turun mencapai permukaan tanah. Hujan yang turun mencapai tanah sebagian masuk ke dalam tanah (resapan), yang akan mengisi pori-pori tanah sebagian mengalir menuju embung sebagai aliran bawah permukaan, sedangkan sisanya mengalir di atas tanah (aliran permukaan).

\section{Struktur Model}

Model NRECA telah diterapkan pada DAS diseluruh Indonesia. Model ini dikhususkan untuk hujan-debit bulanan tetapi dari percobaan yang dilakukan dapat pula diterapkan pada hujan-debit tengah bulanan dengan tidak merubah parameter, berdasarkan keseimbangan air di DAS.

Persamaan keseimbangan tersebut adalah sebagai berikut :

\section{Limpasan $=$ Hujan - Evapotranspirasi aktual + Perubahan tampungan \\ Hujan - Evapotranspirasi aktual + Perubahan tampungan $=$ Limpasan}

Model NRECA membagi aliran bulanan menjadi dua, yaitu limpasan langsung (limpasan permukaan dan bawah permukaan) dan aliran dasar. Tampungan juga dibagi dua yaitu tampungan kelengasan dan tampungan air tanah.

Perubahan tampungan diperhitungkan sebagai selisih dari tampungan akhir dan awal. Simpanan kelengasan ditentukan oleh hujan, evapotranspirasi dan lengas lebih yang selanjutnya menjadi aliran langsung dan imbuhan ke air tanah.

Debit total merupakan jumlah dari aliran langsung ditambah aliran air tanah.

\section{Parameter Karakteristik DAS}

Pada model NRECA ini ada tiga parameter yang menggambarkan karakteristik DAS yang besar pengaruhnya terhadap keluaran sistem, yaitu: 
- Nominal : Indeks kapasitas kelengasan tanah (mm), dapat didekati dengan persamaan : 100 + C. $\mathrm{R}_{\mathrm{a}}$, dimana $\mathrm{C}=0,2$ dan $\mathrm{R}_{\mathrm{a}}=$ hujan tahunan (mm)

- PSUB : PSUB merupakan parameter karakteristik lapisan tanah pada kedalaman 0$2 \mathrm{~m}$. Nilai PSUB berkisar $0.3 \sim 0.9$ tergantung pada sifat lulus air tanah. PSUB $=0.3$ bila bersifat kedap air, PSUB $=0.9$ bila bersifat lulus air.

- GWF : GWF merupakan parameter karakteristik lapisan tanah pada kedalaman 2 $\sim 10 \mathrm{~m} . \mathrm{GWF}=0.2$ bila bersifat lulus air, GWF $=0.8$ bila bersifat kedap air

\section{Kalibrasi Parameter}

Kalibrasi parameter model NRECA dilakukan dengan tujuan mencari parameter yang paling sesuai dengan karakteristik cekungan DAS yang bersangkutan sehingga hidrograf perhitungan akan mendekati hidrograf pengamatan. Karena masukan utama model adalah hujan maka tahap kalibrasi tergantung dari ketersediaan data hujan dan debit.

Ada dua parameter NRECA yang perlu dikalibrasi, yaitu PSUB dan GWF. Disamping itu ada parameter lain diluar struktur model seperti faktor pengali besaran evapotranspirasi dan faktor bobot di setiap pos hujan.

\section{Hasil Analisis}

Mengacu pada penelitian Adidarma dkk, 1996 mengenai Pengwilayahan Parameter Model NRECA untuk Pulau Sumbawa, terdapat hubungan yang cukup erat antara litologi batuan dan kelulusannya yang diperoleh dari peta Hidrogeologi dengan parameter PSUB dan GWF. Kajian hidrogeologi di kabupaten Rote Ndao mengindikasikan dominasi dengan :

- Batuan kwarter

- Batugamping koral, setempat terkarstkan, kelulusan beragam tergantung derajat pembentukan karst.

- Konglomerat dan kerakal bersifat lepas di bagian atas dan padu pada bagian bawah, berkelulusan sedang sampai tinggi di bagian atas.
- Batuan tersier

- Terdiri dari batugamping pejal kelulusan rendah sampai sedang tergantung banyak celahan.

- Terdiri dari konglomerat dan batu gamping, berkelulusan rendah sampai sedang.

Batuan kwarter tersebut dapat mengandung akifer produktif penyebaran luas (berwarna biru) atau produktivitas rendah (berwarna coklat).

Batuan tersier pada umumnya mempunyai akifer berproduktivitas rendah dan langka air tanah dengan PSUB 0,2 dan GWF berkisar antar 0,01 sampai 0,1 (Adidarma dkk, 1996).

Sama halnya dengan batuan kwarter dengan akifer produktivitas rendah. Untuk batuan kwarter dengan akifer produktif yang didimonasi oleh batugamping nilai PSUB berubah menjadi 0,5 dan GWF bergerak antara 0,01 sampai 0,6 (Adidarma dkk, 1996).

Dengan input seperti yang telah dibahas sebelumnya, model NRECA menghasilkan seri data debit simulasi menerus. Rekapitulasi debit andalan (Q80\% dan Q95\%) Embung Wae Robang disajikan pada Tabel 1. berikut.

Tabel 1. Rekapitulasi Debit Andalan Q80\% dan Q95\% ( $\left.\mathrm{m}^{3} / \mathrm{det}\right)$

\begin{tabular}{|c|c|c|c|c|}
\hline \multirow{2}{*}{ No. } & \multirow{2}{*}{\multicolumn{2}{|c|}{ Bulan }} & \multicolumn{2}{|c|}{ Wae Robang } \\
\hline & & & Q80\% & Q95\% \\
\hline \multirow{2}{*}{1} & & 1 & 0,192 & 0,055 \\
\hline & Januarı & 2 & 0,153 & 0,070 \\
\hline \multirow{2}{*}{2} & & 1 & 0,222 & 0,102 \\
\hline & Februari & 2 & 0,198 & 0,108 \\
\hline \multirow{2}{*}{3} & & 1 & 0,184 & 0,102 \\
\hline & Maret & 2 & 0,228 & 0,109 \\
\hline \multirow[b]{2}{*}{4} & & 1 & 0,282 & 0,132 \\
\hline & April & 2 & 0,579 & 0,092 \\
\hline \multirow{2}{*}{5} & Mei & 1 & 0,509 & 0,081 \\
\hline & Me1 & 2 & 0,448 & 0,071 \\
\hline \multirow{2}{*}{6} & Juni & 1 & 0,394 & 0,063 \\
\hline & Juni & 2 & 0,347 & 0,055 \\
\hline \multirow{2}{*}{7} & Juli & 1 & 0,305 & 0,049 \\
\hline & & 2 & 0,269 & 0,043 \\
\hline \multirow{2}{*}{8} & Aoustus & 1 & 0,237 & 0,038 \\
\hline & Agustus & 2 & 0,208 & 0,033 \\
\hline \multirow{2}{*}{9} & & 1 & 0,183 & 0,029 \\
\hline & September & 2 & 0,161 & 0,026 \\
\hline \multirow{2}{*}{10} & & 1 & 0,142 & 0,023 \\
\hline & Oktober & 2 & 0,125 & 0,020 \\
\hline \multirow{2}{*}{11} & November & 1 & 0,110 & 0,017 \\
\hline & Novemoer & 2 & 0,110 & 0,038 \\
\hline \multirow{2}{*}{12} & Desember & 1 & 0,097 & 0,057 \\
\hline & Desember & 2 & 0,169 & 0,076 \\
\hline
\end{tabular}




\section{Kapasitas Tampung}

Embung yang akan dibangun di daerah semi kering akan menampung penuh air di musim hujan dan kemudian dioperasikan selama musim kemarau untuk melayani berbagai kebutuhan. Di NTT musim hujan akan berlangsung 4 bulan (November/ Desember sampai Februari/Maret), sedangkan musim kemarau berlangsung 8 bulan (Maret/ April hingga Oktober/ November).

Di NTT embung dipergunakan untuk melayani kebutuhan penduduk, ternak, dan hewan di suatu desa selama musim kemarau. Di musim hujan penduduk tidak menggunakan air embung untuk memenuhi semua kebutuhannya. Dengan demikian kapasitas tampung embung yang dibutuhkan harus dapat memenuhi kebutuhan di atas juga harus mempertimbangkan kehilangan air oleh penguapan di kolam dan resapan di dasar dan dinding kolam, serta menyediakan ruangan untuk sedimen. Kapasitas tampung yang diperlukan untuk sebuah embung adalah sebagai berikut.

$$
\mathrm{V}_{\mathrm{n}}=\mathrm{V}_{\mathrm{u}}+\mathrm{V}_{\mathrm{e}}+\mathrm{V}_{\mathrm{i}}+\mathrm{V}_{\mathrm{s}}
$$

dimana :

$\mathrm{V}_{\mathrm{n}}=$ kapasitas tampung total yang diperlukan suatu desa $\left(\mathrm{m}^{3}\right)$

$\mathrm{V}_{\mathrm{u}}=$ volume hidup untuk melayani berbagai kebutuhan $\left(\mathrm{m}^{3}\right)$

$\mathrm{V}_{\mathrm{e}}=$ jumlah penguapan dari kolam selama musim kemarau $\left(\mathrm{m}^{3}\right)$

$\mathrm{V}_{\mathrm{i}}=$ jumlah resapan melalui dasar, dinding, dan tubuh embung selama musim kemarau $\left(\mathrm{m}^{3}\right)$

$\mathrm{V}_{\mathrm{s}}=$ ruangan yang disediakan untuk sedimen $\left(\mathrm{m}^{3}\right)$

Dalam menentukan kapasitas total suatu embung harus mempertimbangkan volume/ debit air yang tersedia $\left(\mathrm{V}_{\mathrm{h}}\right)$ dan kemampuan topografi untuk menampung air $\left(\mathrm{V}_{\mathrm{p}}\right)$. Apabila air yang tersedia atau kemampuan topografi kecil, maka embung harus didesain dengan kapasitas yang lebih kecil daripada kebutuhan maksimum suatu desa.

\section{Ketersediaan Air}

Air yang masuk ke dalam embung adalah air permukaan dari seluruh daerah tadah hujan dan air hujan efektif yang langsung jatuh di atas permukaan kolam. Jumlah air yang masuk ke dalam embung adalah sebagai berikut.

$$
\mathrm{V}_{\mathrm{h}}=\sum \mathrm{V}_{\mathrm{j}}+10 . \mathrm{A}_{\mathrm{kt}} \cdot \sum \mathrm{R}_{\mathrm{j}} \text { atau } \mathrm{V}_{\mathrm{h}}=\sum \mathrm{V}_{\mathrm{j}}
$$

dimana :

$\mathrm{V}_{\mathrm{h}}=$ volume air yang dapat mengisi kolam embung selama musim hujan $\left(\mathrm{m}^{3}\right)$

$\mathrm{V}_{\mathrm{j}} \quad=$ aliran bulanan pada bulan $\mathrm{j}\left(\mathrm{m}^{3} /\right.$ bulan $)$

$\sum \mathrm{V}_{\mathrm{j}}=$ jumlah aliran total selama musim hujan $\left(\mathrm{m}^{3}\right)$

$R_{j}=$ curah hujan bulanan pada bulan $\mathrm{j}(\mathrm{mm} /$ bulan)

$\sum \mathrm{R}_{\mathrm{j}}=$ curah hujan total selama musim hujan (mm),

curah hujan musim kemarau diabaikan

$\mathrm{A}_{\mathrm{kt}}=$ luas permukaan kolam embung (ha)

Volume air $\mathrm{V}_{\mathrm{h}}$ merupakan jumlah air maksimum yang dapat mengisi kolam embung. Oleh karena itu air yang tersedia harus dibandingkan dengan kapasitas tampung yang diperlukan $\left(\mathrm{V}_{\mathrm{n}}\right)$ dalam menentukan kapasitas total/ tinggi embung.

Volume air yang dapat mengisi kolam Embung Wae Robang selama musim hujan adalah :

$$
\begin{aligned}
& \sum \mathrm{V}_{\mathrm{j}}=1.737 .293 \mathrm{~m}^{3} \\
& \mathrm{~A}_{\mathrm{kt}}=4,1 \mathrm{ha} \\
& \sum \mathrm{R}_{\mathrm{j}}=896 \mathrm{~mm} \\
& \mathrm{~V}_{\mathrm{h}}=1.737 .293+(10 \times 4,1 \times 896) \\
& =1.774 .029 \mathrm{~m}^{3}
\end{aligned}
$$

\section{Kebutuhan Air dan Tampungan Hidup}

Perhitungan kebutuhan air meliputi 2 (dua) kebutuhan, yaitu kebutuhan air untuk pendudukdan kebutuhan air untuk pertanian. Perhitungan kebutuhan air menggunakan satuan unit analisis kecamatan, karena alasan ketersediaan data-data dasar yang ada, yaitu dalam satuan unit kecamatan.

\section{Kebutuhan Air untuk Penduduk}

Standar kebutuhan air bersih untuk kebutuhan penduduk adalah sebagai berikut.

Tabel 2. Standar Konsumsi Air untuk Kebutuhan Penduduk

\begin{tabular}{llcc}
\hline No. & Kategori Kota & $\begin{array}{c}\text { Jumlah } \\
\text { Penduduk } \\
\text { (jiwa) }\end{array}$ & $\begin{array}{c}\text { Standar } \\
\text { Kebutuhan } \\
\text { Air } \\
\text { (lt/jiwa/hari) }\end{array}$ \\
\hline 1. & Kota & $>$ & 190 \\
2. & Ketropolitan & 1.000 .000 & \\
3. & Kota Besar & $500000-$ & 170 \\
& 1.000 .000 & 150 \\
\hline
\end{tabular}




\begin{tabular}{llll}
\hline 4. & Kota Kecil & $20.000-$ & 130 \\
& 100.000 & \\
5. Kota & $3.000-$ & 100 \\
\hline
\end{tabular}

Sumber : Direktorat Teknik Penyehatan, Ditjen Cipta Karya (1990)

Daerah embung Wae Robang berada di Kecamatan Sano Nggoang. Berdasarkan registrasi penduduk, jumlah penduduk pada tahun $2012 \mathrm{di}$ kecamatan Sano Nggoang sebanyak 13.819 jiwa. Dengan demikian diasumsikan bahwa standar kebutuhan air untuk kebutuhan penduduk di lokasi kajian adalah sebesar $100 \mathrm{lt} /$ jiwa/hari atau $0,10 \mathrm{~m}^{3} /$ jiwa/hari, maka kebutuhan air untuk kebutuhan penduduk adalah sebesar $1.382 \mathrm{~m}^{3} / \mathrm{hari}$

\section{Kebutuhan Air untuk Irigasi}

Faktor yang diperlukan untuk menghitung kebutuhan irigasi adalah :

- Curah Hujan Andalan

- Curah Hujan Rata-Rata

- Evapotranspirasi

- Kebutuhan air di sawah

Kebutuhan air di sawah dipengaruhi oleh:

- Kebutuhan air untuk penyiapan lahan ( PWR )

- Penggunaan konsumtif (ETc)

- Perkolasi atau Rembesan ( P )

- Pergantian lapisan air ( WLR )

- Hujan efektif ( Re )

Perhitungan kebutuhan air irigasi digunakan persamaan :

$$
\mathrm{NFR}=\mathrm{PWR}+\mathrm{P}+\mathrm{WLR}-\mathrm{Re}
$$

- Kehilangan pada jaringan irigasi : Untuk menentukan besarnya debit penyadapan yang berguna untuk merencanakan bangunan pengambilan, maka kebutuhan air irigasi harus ditambah dengan kehilangan pada jaringan tersier, sekunder dan primer.

- Dengan demikian debit penyadapan per ha dihitung dengan persamaan :

$$
\mathrm{DR}=\mathrm{NFR} / \mathrm{e}
$$

Luas potensial areal potensial dihitung berdasarkan keseimbangan air antara debit yang tersedia dan kebutuhan yang diperlukan.
Tabel 3. Luas Areal Potensial (Padi-Padi-

\begin{tabular}{|c|c|c|c|c|}
\hline No. & $\begin{array}{c}\text { Awal } \\
\text { Tanam }\end{array}$ & $\begin{array}{c}\text { Pola } \\
\text { Tanam }\end{array}$ & $\begin{array}{c}\text { Keb. Air } \\
\text { Maksimum } \\
\text { (lt/dt/ha) }\end{array}$ & $\begin{array}{c}\text { Luas } \\
\text { Rencana } \\
\text { (Ha) }\end{array}$ \\
\hline \multirow{3}{*}{1} & Nov.1/ & & & \\
\hline & Mar.1 / & Padi & 1,32 & 106,85 \\
\hline & Jun.2 & Padi & 1,50 & 140,26 \\
\hline \multirow{5}{*}{2} & & Palawija & 0,49 & 107,45 \\
\hline & Nov.2 / & & & \\
\hline & Mar.2 / & Padi & 1,09 & 101,38 \\
\hline & Jul.1 & Padi & 1,31 & 189,88 \\
\hline & & Palawija & 0,46 & 106,85 \\
\hline \multirow{4}{*}{3} & Des.1/ & & & \\
\hline & Apr.1 / & Padi & 1,12 & 86,30 \\
\hline & Jul.2 & Padi & 1,37 & 292,47 \\
\hline & & Palawija & 0,50 & 101,38 \\
\hline \multirow{4}{*}{4} & Des.2 / & & & \\
\hline & Apr.2 / & Padi & 1,12 & 125,18 \\
\hline & Ags. 1 & Padi & 1,37 & 973,49 \\
\hline & & Palawija & 0,48 & 65,99 \\
\hline \multirow{3}{*}{5} & Jan.1 / & & & \\
\hline & Mei.1 / & Padi & 1,58 & 121,82 \\
\hline & Ags. 2 & Padi & 1,45 & 258,41 \\
\hline \multirow{5}{*}{6} & & Palawija & 0,44 & 86,30 \\
\hline & Jan.2 / & & & \\
\hline & Mei.2 / & Padi & 1,27 & 120,55 \\
\hline & Sep.1 & Padi & 1,52 & 206,64 \\
\hline & & Palawija & 1,22 & 157,21 \\
\hline
\end{tabular}
Palawija)

Tabel 4. Luas Areal Potensial (Padi-Palawija-

\begin{tabular}{|c|c|c|c|c|}
\hline No. & $\begin{array}{c}\text { Awal } \\
\text { Tanam }\end{array}$ & $\begin{array}{c}\text { Pola } \\
\text { Tanam }\end{array}$ & $\begin{array}{c}\text { Keb. Air } \\
\text { Maksimum } \\
\text { (lt/dt/ha) }\end{array}$ & $\begin{array}{c}\text { Luas } \\
\text { Rencana } \\
\text { (Ha) } \\
\end{array}$ \\
\hline \multirow{3}{*}{1} & Nov.1/ & & & \\
\hline & Mar.1 / & Padi & 1,70 & 65,74 \\
\hline & Jun.2 & Palawija & 0,46 & 610,00 \\
\hline \multirow{5}{*}{2} & & Palawija & 0,58 & 73,57 \\
\hline & Nov.2 / & & & \\
\hline & Mar.2 / & Padi & 1,70 & 65,99 \\
\hline & Jul.1 & Palawija & 0,50 & 633,04 \\
\hline & & Palawija & 0,59 & 65,74 \\
\hline \multirow{3}{*}{3} & Des.1 / & & & \\
\hline & Apr.1 / & Padi & 1,67 & 72,98 \\
\hline & Jul.2 & Palawija & 0,53 & 866,99 \\
\hline \multirow{5}{*}{4} & & Palawija & 0,61 & 65,74 \\
\hline & Des.2/ & & & \\
\hline & Apr.2/ & Padi & 1,66 & 125,18 \\
\hline & Ags. 1 & Palawija & 0,51 & 973,49 \\
\hline & & Palawija & 0,76 & 65,99 \\
\hline \multirow{3}{*}{5} & Jan.1 / & & & \\
\hline & Mei.1 / & Padi & 1,35 & 121,82 \\
\hline & Ags. 2 & Palawija & 0,52 & 258,41 \\
\hline \multirow{5}{*}{6} & & Palawija & 0,80 & 86,30 \\
\hline & Jan.2 / & & & \\
\hline & Mei.2 / & Padi & 1,35 & 149,30 \\
\hline & Sep.1 & Palawija & 0,51 & 640,88 \\
\hline & & Palawija & 0,78 & 125,18 \\
\hline
\end{tabular}
Palawija)

Dari hasil perhitungan neraca air pada tabel di atas didapat bahwa luas areal terbaik yang dapat dikembangkan untuk DI. Wae Robang yaitu dengan pola tanam padi-padi-palawija dengan masa tanam 


$$
\mathrm{V}_{\mathrm{u}}=240 \times 8.794,37=2.110 .649 \mathrm{~m}^{3}
$$

kebutuhan air $1,12 \mathrm{lt} / \mathrm{dt} / \mathrm{ha}$ atau $96,77 \mathrm{~m}^{3} / \mathrm{hari} / \mathrm{ha}$ dengan luas areal potensial sebesar 125,18 ha. Luas areal DI. Wae Robang yang akan diairi adalah 76,6 ha, maka kebutuhan air irigasi untuk DI. Wae Robang adalah sebesar $7.412 \mathrm{~m}^{3} /$ hari.

\section{Kebutuhan Air untuk Peternakan}

Kebutuhan air untuk kegiatan peternakan meliputi ternak besar dan unggas. Standar kebutuhan air untuk ternak besar adalah $25 \mathrm{lt} / \mathrm{hari} / \mathrm{ekor}$, sedangkan untuk unggas 2,5 lt/hari/ekor.(Dinas Pertanian dalam Suparmoko ,1997)

Hasil perhitungan kebutuhan air untuk peternakan disajikan pada tabel berikut.

Tabel 5. Kebutuhan Air untuk Peternakan

\begin{tabular}{lcc}
\hline $\begin{array}{c}\text { Jenis } \\
\text { Peternakan }\end{array}$ & $\begin{array}{c}\text { Jumlah } \\
\text { (ekor) }\end{array}$ & $\begin{array}{c}\text { Kebutuhan Air } \\
\text { Peternakan } \\
\left(\mathbf{m}^{\mathbf{3} / \text { hari })}\right.\end{array}$ \\
1. Ternak Besar & 12 & 0.29 \\
2. Unggas & 33 & 0.08 \\
Total Kebutuhan Air & 0.37 \\
\hline
\end{tabular}

Dari hasil perhitungan kebutuhan air, maka didapat :

Tabel 6. Kebutuhan Air

\begin{tabular}{ccc}
\hline No. $\begin{array}{c}\text { Jenis Kebutuhan } \\
\text { Air }\end{array}$ & $\begin{array}{c}\text { Kebutuhan Air } \\
\left(\mathbf{m}^{\mathbf{3}} / \mathbf{h a r i}\right)\end{array}$ \\
\hline 1. Penduduk & 1.382 \\
2. Pertanian & \\
a. Irigasi & 7.412 \\
b. Peternakan & 0,37 \\
Total Kebutuhan Air $\left(\mathrm{Q}_{\mathrm{u}}\right)$ & $8.794,37$ \\
\hline
\end{tabular}
adalah :

Kebutuhan total untuk tampungan hidup $\left(\mathrm{V}_{\mathrm{u}}\right)$ dimana :

$$
\mathrm{V}_{\mathrm{u}}=\mathrm{J}_{\mathrm{h}} \times \mathrm{Q}_{\mathrm{u}}
$$

$\mathrm{J}_{\mathrm{h}} \quad=$ jumlah hari selama musim kemarau, yang secara praktis sebesar $=8$ bulan $\times 30$ hari $=$ 240 hari.

$\mathrm{Q}_{\mathrm{u}}=$ kebutuhan air untuk penduduk dan pertanian $\left(\mathrm{m}^{3} /\right.$ hari $)$

Dengan memasukkan besaran di atas, maka jumlah kebutuhan air untuk Embung Wae Robang adalah

\section{Ruang Sedimen $\left(\mathbf{V}_{\mathrm{s}}\right)$}

Ruang untuk sedimen perlu disediakan di kolam embung mengingat daya tampungnya kecil, walaupun daerah tadah hujan disarankan agar ditanami (rumput) untukmengendalikan erosi. Berdasarkan pengamatan pada beberapa embung yang ada di NTT, ruang setinggi 1,00 $\mathrm{m}$ di atas dasar kolam telah cukup untuk menampung sedimen $\left(\mathrm{V}_{\mathrm{s}}\right)$. Ruang ini masih dapat dimanfaatkan selama belum terisi sedimen.

$$
\mathrm{V}_{\mathrm{s}}=0,05-0,1 \mathrm{~V}_{\mathrm{u}}
$$

dimana :

$\mathrm{V}_{\mathrm{u}}=$ volume hidup untuk melayani berbagai kebutuhan $\left(\mathrm{m}^{3}\right)$

$\mathrm{V}_{\mathrm{s}}=$ ruangan yang disediakan untuk sedimen $\left(\mathrm{m}^{3}\right)$

Maka ruangan untuk sedimen yang perlu disediakan untuk Embung Wae Robang adalah :

$\mathrm{V}_{\mathrm{s}}=0,05 \mathrm{~V}_{\mathrm{u}}=0,05 \times 2.110 .649=105.532 \mathrm{~m}^{3}$

\section{Jumlah Penguapan $\left(\mathbf{V}_{\mathrm{e}}\right)$}

Di daerah semi kering penguapan dari kolam embung akan relatif cukup besar jumlahnya apalagi aliran masuk di musim kering tidak ada. Oleh karena itu jumlah penguapan selama musim kemarau perlu diperhitungkan dalam penentuan kapasitas atau tinggi embung. Penguapan di permukaan kolam embung dapat dihitung sebagai berikut.

$$
\mathrm{V}_{\mathrm{e}}=10 . \mathrm{A}_{\mathrm{kt}} \cdot \sum \mathrm{E}_{\mathrm{kj}}
$$

dimana :

$\mathrm{V}_{\mathrm{e}}=$ jumlah penguapan dari kolam selama musim kemarau $\left(\mathrm{m}^{3}\right)$

$\mathrm{A}_{\mathrm{kt}}=$ luas permukaan kolam embung

$\mathrm{E}_{\mathrm{kj}}=$ penguapan bulanan di musim kemarau pada bulan ke-j (mm/bulan), didapat dengan mengalikan besaran penguapan panci A dengan koefisien embung 0,70 .

Luas permukaan kolam Embung Wae Robang adalah 4,1 ha. Jumlah penguapan bulanan di musim 
kemarau adalah $1049 \mathrm{~mm} / \mathrm{bulan}$. Maka jumlah penguapan dari kolam selama musim kemarau untuk Embung Wae Robang adalah :

$V_{e}=10 \times 4,1 \times 1049=43.009 \mathrm{~m}^{3}$

\section{Jumlah Resapan $\left(\mathbf{V}_{\mathbf{i}}\right)$}

Air di dalam kolam embung akan meresap masuk ke dalam pori atau rongga di dasar dan dinding kolam. Besarnya resapan ini tergantung dari sifat lulus air material dasar dan dinding kolam, sifat ini tergantung pada jenis butiran tanah atau struktur batu pembentuk dasar dan dinding kolam. Berdasarkan beberapa analisis teoritik oleh Pusat Penelitian dan Pengembangan Sumber Daya Air (1993) pada 15 tempat embung di Pulau Flores, besarnya resapan air kolam embung adalah sebagai berikut.

$\mathrm{V}_{\mathrm{i}}=\mathrm{K} \cdot \mathrm{V}_{\mathrm{u}}$

dimana :

$\mathrm{V}_{\mathrm{i}}=$ jumlah resapan tahunan $\left(\mathrm{m}^{3}\right)$

$\mathrm{V}_{\mathrm{u}}=$ jumlah air untuk berbagai kebutuhan $\left(\mathrm{m}^{3}\right)$

$\mathrm{K}$ = faktor yang nilainya tergantung dari sifat lulus air material dasar dan dinding kolam embung.

$\mathrm{K}=10 \%$, bila dasar dan dinding kolam embung praktis rapat air $\left(\mathrm{k} \mathrm{d} " 10^{-5} \mathrm{~cm} / \mathrm{det}\right)$, termasuk penggunaan lapisan buatan (selimut lempung, geomembran, semen-tanah).

$\mathrm{K}=25 \%$, bila dasar dan dinding kolam embung bersifat semi lulus air $\left(\mathrm{k} \mathrm{d"} 10^{-3}-10^{-4} \mathrm{~cm} / \mathrm{det}\right)$.

Jumlah resapan tahunan untuk Embung Wae Robang adalah :

$$
\mathrm{V}_{\mathrm{i}}=0,25 \times 2.110 .649=527.662 \mathrm{~m}^{3}
$$

\section{Kapasitas Tampung Desain $\left(\mathbf{V}_{d}\right)$}

Untuk menentukan kapasitas tampung desain suatu embung $\left(\mathrm{V}_{\mathrm{d}}\right)$ harus membandingkan ketiga hal, yaitu :

- $\quad$ Volume tampungan yang diperlukan $\left(\mathrm{V}_{\mathrm{n}}\right)$ untuk menyediakan :

- kebutuhan penduduk dan pertanian $\left(\mathrm{V}_{\mathrm{u}}\right)$ di suatu desa.

- volume cadangan untuk kehilangan air karena penguapan $\left(\mathrm{V}_{\mathrm{e}}\right)$ dan resapan $\left(\mathrm{V}_{\mathrm{i}}\right)$.

- ruangan untuk menampung sedimen $\left(\mathrm{V}_{\mathrm{s}}\right)$.

$$
\mathrm{V}_{\mathrm{n}}=\mathrm{V}_{\mathrm{u}}+\mathrm{V}_{\mathrm{e}}+\mathrm{V}_{\mathrm{i}}+\mathrm{V}_{\mathrm{s}}
$$

Kapasitas tampungan yang diperlukan adalah :

$$
\begin{aligned}
\mathrm{V}_{\mathrm{n}} & =2.110 .649+43.009+527.662+105.532 \\
& =2.786 .852 \mathrm{~m}^{3}
\end{aligned}
$$

- Volume air yang tersedia (potensial) selama musim hujan $\left(\mathrm{V}_{\mathrm{h}}\right)$ yang merupakan jumlah air maksimum yang dapat mengisi kolam embung.

- Daya tampung (potensi) topografi untuk menampung air $\left(\mathrm{V}_{\mathrm{p}}\right)$.

Dari ketiga besaran tersebut, yaitu $V_{n}, V_{h}$, dan $\mathrm{V}_{\mathrm{p}}$ dipilih yang terkecil sebagai volume/ kapasitas tampung desain suatu embung $\left(\mathrm{V}_{\mathrm{d}}\right)$. Perbandingan nilai $\mathrm{V}_{\mathrm{n}}, \mathrm{V}_{\mathrm{h}}$, dan $\mathrm{V}_{\mathrm{p}}$ adalah sebagai berikut :

$\mathrm{V}_{\mathrm{n}}=2.786 .852 \mathrm{~m}^{3}$

$\mathrm{V}_{\mathrm{h}}=1.774 .029 \mathrm{~m}^{3}$

$\mathrm{V}_{\mathrm{p}}=1.348 .859 \mathrm{~m}^{3}$

Dari data atas menunjukkan bahwa daya tampung (potensi) topografi untuk menampung air $\left(\mathrm{V}_{\mathrm{p}}\right)$ merupakan volume yang paling kecil, maka kapasitas tampung desain embung $\left(\mathrm{V}_{\mathrm{d}}\right)$ adalah sebagai berikut :

Kapasitas tampung desain embung Wae Robang $\left(\mathrm{V}_{\mathrm{d}}\right)=1.348 .859 \mathrm{~m}^{3}$.

Oleh karena nilai $\mathrm{V}_{\mathrm{p}}$ yang menentukan, maka perlu dihitung berapa kebutuhan air yang dapat dilayani oleh embung yang hendak dibangun.

$$
\mathrm{V}_{\mathrm{u}}=\mathrm{V}_{\mathrm{d}}-\mathrm{V}_{\mathrm{e}}-\mathrm{V}_{\mathrm{i}}-\mathrm{V}_{\mathrm{s}}
$$

dimana $\mathrm{V}_{\mathrm{d}}=$ kapasitas desain embung sebesar nilai terkecil dari $\mathrm{V}_{\mathrm{n}}, \mathrm{V}_{\mathrm{h}}$, dan $\mathrm{V}_{\mathrm{p} \text {. }}$.

Untuk Embung Wae Robang, kebutuhan air yang dapat dilayani sebesar :

$$
\begin{aligned}
\mathrm{V}_{\mathrm{u}} & =1.348 .859-43.009-527.662-105.532 \\
& =672.656 \mathrm{~m}^{3}
\end{aligned}
$$

Maka selama 8 bulan musim kemarau Embung Wae Robang dapat melayani kebutuhan air sebesar

$$
\mathrm{Q}_{\mathrm{u}}=\frac{\mathrm{V}_{\mathrm{u}}}{\mathrm{J}_{\mathrm{h}}}=\frac{672.656}{240}
$$




$$
=2803 \mathrm{~m}^{3} / \text { hari }
$$

Volume tampungan yang diperlukan $\left(\mathrm{V}_{\mathrm{n}}\right)$ untuk memenuhi :

- kebutuhan penduduk sebesar $1.382 \mathrm{~m}^{3} /$ hari

- kebutuhan pertanian :

- irigasi sebesar $4.238 \mathrm{~m}^{3} /$ hari dengan luas areal irigasi yang dapat diairi seluas 43,79 ha.

- peternakan sebesar $0,37 \mathrm{~m}^{3} /$ hari

\section{Debit Banjir}

Embung air bersih harus dilengkapi dengan bangunan pelimpah yang memerlukan besaran banjir rencana untuk merencanakan ukurannya.

Karena luas tangkapan hujan untuk embung ini kecil dan kapasitas embung juga kecil, maka kapasitas bangunan pelimpahnya didesain berdasarkan kala ulang paling besar 50 tahun. Oleh karena itu metoda yang digunakan adalah yang metoda rasional. (Kasiro,1994).

Metoda rasional yang digunakan untuk luas daerah tangkapan hujan untuk embung kecil adalah Metode Rasional dari Singapura dan Australia (Kasiro,1994).

Tahun 1993 Pusat Litbang Pengairan telah mengadakan studi perbandingan tentang intensitas hujan untuk memodifikasi metode ini agar sesuai dengan kebutuhan lokal. Hasilnya menyimpulkan adanya kemiripan intensitas hujan di Jakarta, Australia, dan Singapura, dimana besarnya hujan maksimum harian rata-rata mendekati $100 \mathrm{~mm}$ dan jumlah hari hujan dalam setahun rata-rata lebih dari 50 hari. Metoda ini dapat pula diterapkan di daerah urban lain.

Metode Rasional Singapura dan Australia membutuhkan intensitas hujan ( $\mathrm{mm} / \mathrm{jam})$ atau tinggi hujan $(\mathrm{mm})$ dengan durasi yang dianggap sebesar waktu konsentrasinya dengan kala ulang tertentu.

Dalam perhitungan ini dibutuhkan peta topografi daerah tadah hujan dengan skala minimal $1: 2000$, untuk menentukan luas daerah tadah hujan, tempat embung, panjang alur, dan perbedaan ketinggian rata-rata antara tempat embung dan tinggi tertinggi dalam daerah tadah hujan.

\section{Metoda Rasional Singapura}

Persamaan yang digunakan dalam menentukan debit puncak dengan Metoda Rasional Singapura ini adalah sebagai berikut:

$$
\begin{aligned}
\mathrm{u}=\frac{\mathrm{n} \times \mathrm{L}}{S^{0,5}} \\
\mathrm{i}_{5}=\mathrm{i}_{\mathrm{e} 5}+\mathrm{f} \\
\mathrm{t}_{\mathrm{c}}=\left(\mathrm{a}_{\mathrm{n}} / \mathrm{i}_{5}\right)^{1 / \mathrm{b}_{\mathrm{n}}} \\
\mathrm{C}=\mathrm{i}_{\mathrm{e} 5} / \mathrm{i}_{5} \\
\mathrm{i}_{\mathrm{T}}=\mathrm{a}_{\mathrm{n}} \mathrm{t}_{\mathrm{c}}-\mathrm{bn} \\
\mathrm{Q}_{\mathrm{T}}=\frac{\mathrm{C} * \mathrm{i}_{\mathrm{T}} * \mathrm{~A}}{360}
\end{aligned}
$$

dimana :

$\mathrm{u}=$ parameter daerah tadah hujan

$\mathrm{n}=$ koefisien kekasaran Manning

$\mathrm{L}=$ panjang daerah overland $(\mathrm{m})$

$\mathrm{S}=$ kemiringan daerah overland $(\mathrm{m} / \mathrm{m})$

$\mathrm{i}_{5}=$ intensitas hujan selama waktu konsentrasi pada

kala ulang 5 tahun ( $\mathrm{mm} / \mathrm{jam})$

$\mathrm{i}_{\mathrm{e} 5}=$ intensitas hujan efektif 5 tahunan ( $\left.\mathrm{mm} / \mathrm{jam}\right)$

$\mathrm{f}=$ kecepatan infiltrasi $(\mathrm{mm} / \mathrm{jam})$ yang nilainya tergantung sifat lulus air lahan

$\mathrm{i}_{\mathrm{T}}=$ intensitas hujan pada kala ulang $\mathrm{T}$ ( $\left.\mathrm{mm} / \mathrm{jam}\right)$

$\mathrm{t}_{\mathrm{c}}=$ durasi hujan atau waktu konsentrasi (menit)

$\mathrm{C}=$ koefisien limpasan

$\mathrm{A}=$ luas daerah tadah hujan (ha)

$\mathrm{Q}_{\mathrm{T}}=$ debit puncak banjir untuk kala ulang $\mathrm{T}$ tahun

Tabel 7. Koefisien Kekasaran Manning n

\begin{tabular}{lc}
\hline \multicolumn{1}{c}{ Jenis Penutup Lahan } & n \\
\hline Rumput pendek & 0,035 \\
Rumput tinggi & 0,050 \\
Daerah tanpa tanaman & 0,040 \\
Daerah dengan tanaman yang berjajar & 0,045 \\
Daerah dengan tanaman beraneka ragam & 0,050 \\
Semak yang sangat jarang & 0,070 \\
Semak dan pohon yang jarang & 0,080 \\
Semak yang sedang sampai lebat & 0,160 \\
Pohon-pohon kecil yang lebat & 0,200 \\
Daerah tandus dengan tunggul-tunggul kayu & 0,050 \\
Daerah tandus dengan tunggul-tunggul kayu & 0,080 \\
dan tanaman selingan & \\
Hutan kayu yang lebat dan tanaman selingan & 0,120 \\
\hline
\end{tabular}

(Sumber : Kasiro, 1994)

Tabel 8. Kecepatan Infiltrasi

\begin{tabular}{lc}
\multicolumn{1}{c}{ Sifat Lulus Air Lahan } & $\begin{array}{c}\mathbf{f} \\
\text { (mm/jam) }\end{array}$ \\
\hline 1. Kedap air & 0 \\
2. Semi lulus air & $10-20$ \\
3. Lulus air & 30 \\
\hline
\end{tabular}

(Sumber : Kasiro, 1994) 
Hasil perhitungan debit banjir rencana dengan Metoda Rasional Singapura disajikan pada tabel berikut.

Tabel 9. Debit Banjir Rencana dengan Metoda Rasional Singapura

\begin{tabular}{cc}
\hline $\begin{array}{c}\text { Periode Ulang } \\
\text { (Tahun) }\end{array}$ & $\begin{array}{c}\text { Debit Banjir } \\
\left(\mathbf{m}_{\mathbf{3}} \text { /det }\right)\end{array}$ \\
\hline 2 & 12,83 \\
5 & 15,65 \\
10 & 16,37 \\
20 & 17,82 \\
25 & 18,55 \\
50 & 21,52 \\
\hline
\end{tabular}

\section{Metoda Rasional Australia}

Cara menentukan debit puncak dengan metoda rasional ini adalah sebagai berikut :

- 1Menentukan hujan harian maksimum tahunan yang dirata-ratakan $\left(\mathrm{R}_{\mathrm{m}}\right)$ dan jumlah hari hujan badai (M) yang lebih besar dari $10 \mathrm{~mm}$ per hari.

- Waktu konsentrasi $\left(\mathrm{t}_{\mathrm{c}}\right.$ ) didefinisikan sebagai waktu yang dibutuhkan oleh limpasan untuk melalui jarak terjauh di daerah tadah hujan, yaitu dari suatu titik di hulu sampai ke titik tinjau paling hilir. Waktu konsentrasi dihitung dengan menggunakan rumus Kirpich dan rumus Giandotti, kemudian dua harga tersebut dirataratakan.

Rumus Kirpich :

$$
\mathrm{t}_{\mathrm{c}}=0,945 \frac{\mathrm{L}^{1,156}}{\mathrm{D}^{0,385}}
$$

Rumus Giandotti :

$$
\mathrm{t}_{\mathrm{c}}=0,945 \frac{\mathrm{L}^{1,156}}{\mathrm{D}^{0,385}}
$$

dimana :

$\mathrm{t}_{\mathrm{c}}=$ waktu konsentrasi (menit)

$\mathrm{L}=$ panjang sungai utama $(\mathrm{km})$

$\mathrm{D}=$ perbedaan tinggi antara lokasi embung dan titik tertinggi pada daerah tadah hujan.

$\mathrm{h}=$ perbedaan antara tinggi rata-rata dari daerah tadah hujan dan ketinggian lokasi embung (m)

- $\quad$ Perhitungan curah hujan (R)

- Untuk $\mathrm{t}_{\mathrm{c}}=5$ sampai 120 menit dengan kala ulang 2 sampai dengan 100 tahun:

$R_{T}^{t}=R_{60}^{2}(0,35 \ln T+0,76)\left(0,54 t_{c}{ }_{c}^{0,25}-0,5\right)$
- Untuk t lebih dari 120 menit dengan kala ulang 2 sampai dengan 100 tahun :

$$
\mathrm{R}_{\mathrm{T}}^{\mathrm{t}}=\mathrm{R}_{60}^{2}(0,35 \ln \mathrm{T}+0,76)\left(0,5 \mathrm{\xi}^{0,25}-0,5\right)-[0,1(\mathrm{t}-120)+1]
$$

dimana :

$\mathrm{R}_{\mathrm{T}}^{\mathrm{t}}=$ hujan dalam $\mathrm{mm}$ untuk durasi $\mathrm{t}$ menit yang sama dengan waktu konsentrasi tc untuk kala ulang T tahun

$\mathrm{R}_{60}^{2}=$ hujan untuk durasi 60 menit dengan kala ulang 2 tahun dapat dihitung dengan rumus Bell yang dimodifikasi oleh Pusat Litbang Pengairan. Rumus ini berlaku untuk seluruh daerah semi kering di Indonesia.

$$
\begin{aligned}
\mathrm{R}_{60}^{2}=0,17 \mathrm{R}_{\mathrm{m}} \mathrm{M}^{0,33} \text { untuk } 0<\mathrm{M} & <50 ; \\
& 80 \mathrm{~d} \text { " } \mathrm{R} \mathrm{d} \text { " } 115 \\
& \mathrm{R}_{60}^{2} \text { dan } \mathrm{R}_{\mathrm{m}} \text { dalam }
\end{aligned}
$$

mm, M dalam hari

- Perhitungan intensitas hujan

dimana :

$$
\mathrm{i}_{\mathrm{T}}=\mathrm{R}_{\mathrm{T}}^{\mathrm{t}} / \mathrm{t}_{\mathrm{c}}
$$

$\mathrm{i}_{\mathrm{T}}=$ intensitas hujan pada kala ulang $\mathrm{T}(\mathrm{mm} /$ jam)

$\mathrm{R}_{\mathrm{T}}^{\mathrm{t}}=$ hujan dalam mm

$\mathrm{t}_{\mathrm{c}}=$ waktu konsentrasi (menit)

- $\quad$ Perhitungan koefisien limpasan (C)

Koefisien limpasan dapat dihitung dengan memperhatikan faktor iklim dan fisiografi, yaitu dengan menjumlahkan beberapa koefisien $\mathrm{C}$ sebagi berikut :

dimana :

$$
\mathrm{C}=\mathrm{C}_{\mathrm{p}}+\mathrm{C}_{\mathrm{t}}+\mathrm{C}_{\mathrm{o}}+\mathrm{C}_{\mathrm{s}}+\mathrm{C}_{\mathrm{c}}
$$

$\mathrm{C}_{\mathrm{p}}=$ komponen $\mathrm{C}$ yang disebabkan oleh intensitas hujan yang bervariasi.

$\mathrm{C}_{\mathrm{t}}=$ komponen $\mathrm{C}$ yang disebabkan oleh keadaan topografi.

$\mathrm{C}_{\mathrm{o}}=$ komponen $\mathrm{C}$ yang disebabkan oleh tampungan permukaan.

$\mathrm{C}_{\mathrm{s}}=$ komponen $\mathrm{C}$ yang disebabkan oleh infiltrasi.

$\mathrm{C}_{\mathrm{c}}=$ komponen $\mathrm{C}$ yang disebabkan oleh penutup lahan. 
Tabel 10. Harga Komponen C oleh Faktor Intensitas Hujan

\begin{tabular}{cc}
\hline Intensitas Hujan (mm/jam) & $\mathbf{C}_{\mathbf{p}}$ \\
\hline$<25$ & 0,05 \\
$25-50$ & 0,15 \\
$50-75$ & 0,25 \\
$>75$ & 0,30 \\
\hline
\end{tabular}

Sumber : Kasiro, 1994)

Tabel 11. Harga Komponen C oleh Faktor Topografi

\begin{tabular}{lcc}
\hline \multicolumn{1}{c}{ Keadaan Topografi } & $\begin{array}{c}\text { Kemiringan } \\
\mathbf{m} / \mathbf{k m}\end{array}$ & $\mathbf{C}_{\mathbf{t}}$ \\
\hline Curam dan tidak rata & 200 & 0,10 \\
Berbukit-bukit & $100-200$ & 0,05 \\
Landai & $50-100$ & 0,00 \\
Hampir datar & $0-50$ & 0,00 \\
\hline
\end{tabular}

(Sumber : Kasiro, 1994)

Tabel 12. Harga Komponen C oleh Tampungan Permukaan

\begin{tabular}{lc}
\hline \multicolumn{1}{c}{ Tampungan Permukaan } & $\mathbf{C}_{\mathbf{0}}$ \\
\hline $\begin{array}{l}\text { 1. Daerah pengaliran yang curam, sedikit } \\
\text { depresi permukaan }\end{array}$ & 0,10 \\
2. Daerah pengaliran yang sempit dengan \\
$\begin{array}{l}\text { sistem teratur } \\
\text { 3. Tampungan dan aliran permukaan yang } \\
\text { berair, terdapat kolam, berkontur }\end{array}$ & 0,05 \\
$\begin{array}{l}\text { 4. Sungai berkelok-kelok dengan usaha } \\
\text { pelestarian alam }\end{array}$ & 0,05 \\
\hline
\end{tabular}

(Sumber : Kasiro, 1994)

Tabel 13. Harga Komponen C oleh Faktor

\begin{tabular}{lcc}
\multicolumn{3}{c}{ Infiltrasi } \\
Kemampuan Infiltrasi Lahan & $\begin{array}{c}\mathbf{k} \\
(\mathbf{c m} / \mathbf{d e t})\end{array}$ & $\mathbf{C}_{\mathbf{s}}$ \\
\hline Infiltrasi besar (tidak terdapat & $<10^{-5}$ & 0,25 \\
penutup lahan) & $10^{-5}-10^{-6}$ & 0,20 \\
Infiltrasi lambat (lempung) & $10^{-3}-10^{-4}$ & 0,10 \\
Infiltrasi sedang (loam) & $10^{-3}$ & 0,05 \\
$\begin{array}{l}\text { Infiltrasi cepat (pasir tebal, tanah } \\
\text { beragregat baik) }\end{array}$ & & \\
\hline
\end{tabular}

(Sumber : Kasiro, 1994)

Tabel 14. Harga Komponen C oleh Penutup Lahan

\begin{tabular}{llc}
\hline \multicolumn{1}{c}{$\begin{array}{c}\text { Penutup Tumbuh-tumbuhan pada Daerah } \\
\text { Pengaliran }\end{array}$} & $\mathbf{C}_{\mathbf{c}}$ \\
\hline 1. Tidak terdapat tanaman yang efektif & 0,25 \\
2. Terdapat padang rumput yang baik sebesar 10\% & 0,20 \\
3. Terdapat padang rumput yang baik sebesar & 0,10 \\
$\begin{array}{l}\text { 50\%, ditanami atau banyak pepohonan } \\
\text { 4. Terdapat padang rumput yang baik sebesar 90\%, } \\
\text { hutan }\end{array}$ & 0,05 \\
\hline
\end{tabular}

- $\quad$ Perhitungan debit puncak banjir $\left(\mathrm{Q}_{\mathrm{T}}\right)$

$$
\mathrm{Q}_{\mathrm{T}}=\frac{\mathrm{C} \cdot \mathrm{i}_{\mathrm{T}} \cdot \mathrm{A}}{3,6}
$$

dimana :

$\mathrm{Q}_{\mathrm{T}}=$ debit puncak banjir untuk kala ulang $\mathrm{T}$ tahun

$\mathrm{C}=$ koefisien runoff total

$\mathrm{i}_{\mathrm{T}}=$ intensitas hujan pada kala ulang $\mathrm{T}(\mathrm{mm} /$ jam)

$\mathrm{A}=$ luas daerah tadah hujan $\left(\mathrm{km}^{2}\right)$

Hasil perhitungan debit banjir rencana dengan Metoda Rasional Singapura dan Metoda

Rasional Australia disajikan pada tabel berikut.

Tabel 15. Debit Banjir Rencana dengan Metoda Rasional Australia

\begin{tabular}{cc}
\hline $\begin{array}{c}\text { Periode Ulang } \\
\text { (Tahun) }\end{array}$ & $\begin{array}{c}\text { Debit Banjir } \\
\text { (m3/det) }\end{array}$ \\
\hline 2 & 10,22 \\
5 & 13,49 \\
10 & 15,97 \\
20 & 18,44 \\
25 & 19,24 \\
50 & 21,71 \\
\hline
\end{tabular}

Penentuan banjir rencana dipilih berdasarkan hasil perhitungan di atas dan kondisi di lapangan yang didapatkan dari informasi penduduk setempat maupun dari data pengamatan banjir yang pernah terjadi. Banjir rencana ditentukan berdasarkan kriteria-kriteria antara lain :

- harus memenuhi batasan kapasitas sungai (bank full capacity),

- besaran maksimum yang mungkin berdasarkan data rekaman,

- $\quad$ prediksi parameter DAS

Untuk DAS Wae Robang, dengan luas 62,6 ha, debit palung dihitung berdasarkan debit dari luas penampang sungai di lapangan, didapat $Q=10,6$ $\mathrm{m}^{3} /$ det. Debit palung mendekati nilai pendekatan dari debit periode ulang 2 tahunan dengan Metode Rasional Australia.

\section{KESIMPULAN DAN SARAN}

\section{Kesimpulan}


Dari hasil analisis hidrologi didapatkan kesimpulan sebagai berikut :

- Volume air yang dapat mengisi kolam Embung Wae Robang selama musim hujan adalah sebesar $1.774 .029 \mathrm{~m}^{3}$.

- Kapasitas tampung desain embung Wae Robang adalah sebesar $1.348 .859 \mathrm{~m}^{3}$.

- Debit banjir rencana dengan kala ulang 50 tahun untuk pelimpah embung Wae Robang adalah sebesar $21,71 \mathrm{~m}^{3} / \mathrm{det}$.

\section{Saran}

Perlu adanya penelitian selanjutnya untuk menganalisa erosi dan sedimentasi lahan sehingga dapat diketahui umur layanan embung Wae Robang.

\section{DAFTAR PUSTAKA}

HEC-1.1990, Flood Hydrograph Package, User's Manual. Hydrologic Engineers Centre. U.S. Army Corps of Engineer.

Jasapatria Gunatama, PT., Studi Perencanaan Embung Irigasi/ Air Baku 2 buah di Flores. Tidak dipublikasikan.

Kasiro, Ibnu, dkk. 1994. Pedoman Kriteria Desain Embung Kecil untuk Daerah Semi Kering di Indonesia. Departemen Pekerjaan Umum. Soemarto. 1986. Hidrologi Teknik. Usaha Nasional. Surabaya-Indonesia.

Soewarno. 1995. Aplikasi Metode Statistik untuk Analisa Data. Jilid 1. Bandung : NOVA

Soewarno. 1991. Pengukuran dan Pengolahan Data Aliran Sungai (Hidrometri). Bandung : NOVA 